\title{
Effects of Self-Instruction and Time Management Techniques in Group Counseling to Reduce Academic Procrastination
}

\author{
(Pengaruh Teknik Self-Instruction dan Time Management dalam Konseling Kelompok untuk \\ Menurunkan Prokrastinasi Akademik) \\ Dahlia Novarianing Asri*, Asroful Kadafi \\ Departmenet of Guidance and Counseling, Faculty of Teacher Training and Education, Universitas PGRI Madiun, \\ Setiabudi Street No. 85, Madiun, East Java, 63118 Indonesia \\ *corresponding author, e-mail: novarianing@unipma.ac.id
}

Article received: March $10^{\text {th }} 2020$; revised: June $19^{\text {th }} 2020$; accepted: July $1^{\text {st }} 2020$

\begin{abstract}
This study aims to discover the effectiveness of group counseling with self-instruction and time management techniques in decreasing academic procrastination in mathematics learning. This research used a randomized pre-test post-test comparison group design with sixteen participants selected through a purposive random sampling technique. Eight of those participants (group 1) used the selfinstruction technique; meanwhile, the other eight participants (groups 2) used the time management technique. The data was obtained through an academic procrastination scale, referring to academic procrastination aspects, developed by Tuckman. Additionally, the Wilcoxon Signed Rank Test was used to test the effectiveness of both techniques, and the Mann-Whitney test was used to compare the efficacy of both techniques. The results indicate that group counseling with self-instruction and time management techniques are sufficient to lower the academic procrastination in mathematics learning. Further, the self-instruction group counseling is more effective to downturn academic procrastination than time management technique.
\end{abstract}

Keywords: group counseling; self-instruction technique; time management technique; academic procrastination

\begin{abstract}
Abstrak: Penelitian ini bertujuan untuk menguji keefektifan konseling kelompok dengan teknik selfinstruction dan teknik time management untuk mereduksi prokrastinasi akademik pada pembelajaran matematika. Desain penelitian menggunakan randomized pre-test post-test comparison group design. Enam belas subjek penelitian dipilih menggunakan teknik purposive random sampling, dimana delapan subjek (kelompok 1) diberi perlakuan teknik self-instruction dan delapan lainnya (kelompok 2) diberi perlakuan teknik time management. Data dikumpulkan menggunakan skala prokrastinasi akademik yang dikembangkan oleh Tuckman dengan mengacu pada aspek prokrastinasi akademik. Wilcoxon Signed Rank Test digunakan untuk menguji keefektifan kedua teknik, sementara uji MannWhitney digunakan untuk membandingkan keefektifan keduanya. Hasil penelitian menunjukkan bahwa konseling kelompok dengan teknik self-instruction dan teknik time management efektif untuk mereduksi prokrastinasi akademik pada pembelajaran matematika. Lebih lanjut, konseling kelompok dengan teknik self-instruction lebih efektif untuk mereduksi prokrastinasi akademik dibandingkan teknik time management.
\end{abstract}

Kata kunci: konseling kelompok; teknik instruksi diri; teknik manajemen waktu; prokrastinasi akademik 


\section{INTRODUCTION}

Academic procrastination is a common issue faced by students in their educational activity (Munawaroh, Alhadi, \& Saputra, 2017; Utaminingsih \& Setyabudi, 2012; Widiseno, Purwanti, \& Wicaksono, 2018). Findings from a study conducted by Savira \& Suharsono (2013) reveal that $52.1 \%$ of 12th grade senior high school students in Malang city possess a high level of academic procrastination; meanwhile, the other $47.9 \%$ students have low academic procrastination level. The high rate of academic procrastination is identified from students' behavior in finishing the tasks, late task submission, and prioritizing other activities while working on the assignments.

Mathematics is a course perceived as challenging and frequently avoided by students. Consequently, students tend to procrastinate in this course. Academic procrastination in mathematics is experienced by thousands of students (Asikhia, 2010). The number of students with excellent mathematic comprehension is relatively low due to the minimum attention and time allocated for it. This is caused by mathematics learning that regularly emphasizes on counting skills, while less accentuating on logical and problemsolving activities. Thus, this subject is perceived as boring by students, so that many of them dislike it. Students' negative perceptions toward this course can generate low mathematic learning achievement. The results of TIMSS' (Trends in International Mathematics and Science Study) study in 2015 finds that Indonesia is at 44th rank among 49 countries (Hadi \& Novaliyosi, 2019). One of the causes of low mathematics achievement is the behavior of postponing finishing the assignment or commonly known as academic procrastination (Asri, Setyosari, \& Chusniyah, 2017).

According to a study carried out by Asri et al. (2017), 52.6\% and 47.4\% of students from 7 th state grade junior high schools in Madiun district have a high and low rate of academic procrastination, respectively. This is also supported by interview results with mathematics teachers from ten junior high schools in the Madiun district. The interview result indicates low students' awareness of the importance of the assignments given by the teachers. When they are handed out the task, many students still do it in class, minutes before the course is started, by copying their friend's answer. Some of them finish the assignments carelessly. Besides, students find that the teachers' teaching methods are less exciting and rather dull. Thus, teachers have to adopt more interesting teaching techniques.

The interview results also illustrate that high academic procrastination is also caused by many students that perceive the given tasks are less critical. They tend to prioritize other recreative tasks to spend their free time so that they cannot finish the tasks distributed by teachers on time. Based on the preliminary research through the interview with students, only a small number of teachers apply discipline in the academic task submission. Thus, many students submit their tasks late and get no consequences or punishment. Therefore, students keep repeating this procrastination behavior. Besides, the results of students interviews also reveal that teacher indicator only covers whether or not students have submitted the tasks. If they collect the assignment, the teacher has no information on whether the task is finished right after it is distributed or at the last minutes before the submission is due.

From the cognitive-behavioral perspective, procrastination is defined as: (1) task avoidance behavior that leads into late task completion; (2) personality trait (Talask \& Carvalho, 2017). Both conscientiousness and neuroticism are connected to the 'Big Five' personality dimensions to comprehend procrastination as a personality trait. All conscientiousness aspects, such as time management, selfcontrol, and self-discipline, become the most significant predictor of procrastination; on the other hand, neuroticism aspects, including impulsivity and vulnerability, is procrastination predictor that present the correlation between procrastination, depression, and self-awareness (Talask \& Carvalho, 2017).

The cognitive behavior therapy perspective bears some studies on procrastination related to the cognitive distortion that is regarded as someone's effort to understand fundamental phenomena. The studies discuss both academic procrastination and general procrastination that mostly shows low selfregard, self-efficacy, and self-critical behavior, as well as irrational anxiety on success and failure (Asikhia, 2010; Ozer \& Saricaoglu, 2013; Park \& Sperling, 2012; Patrzek, Grunschel, \& Fries, 2012; Saleem \& Rafique, 2012). These cognitive distortions come from a high standard, along with the wrong perception of school tasks, such as perceiving tasks as a substantial tiresome burden (task aversiveness) and fear of failure. A tremendous rate of fear of failure creates anxiety and worry in fulfilling the assignment deadline. Lowering the concern by refraining from the stimulus (procrastination) and its consequences 
construct a more robust avoidance behavior (Azure, 2011; Haghbin, McCaffrey, \& Phychyl, 2012; Jiao, Daros-Voseles, Collins, \& Onwuegbuzie, 2011; Motie, Heidari, \& Sadhegi, 2012; Seperiah \& Lotf, 2011).

Some characteristics that lead to academic procrastination are classified as internal factors, such as task-aversiveness, fear of failure, low self-confident, low self-regulation in learning, perfectionism, anxiety, poor learning behavior (Afzal, S., \& Jami, 2018; Haghbin et al., 2012; Patrzek et al., 2012; Procee, Kamphorst, Meyer, \& Wissen, 2013; Wilson, 2012) and low time-management skills (Gafni \& Geri, 2010; Naturil-Alfonso, Penaranda, Vicente, \& Marco-Jimenez, 2018). Research completed by Asri et al. (2017) concludes that students' academic procrastination in the mathematic subject is generated from failure in self-regulated learning.

On the other hand, the external factors of procrastination involve low social support, the role of parents, learning duration at school, the teaching quality of teachers, and the implementation of discipline in the school learning process (Esmaeili \& Monadi, 2016; Patrzek et al., 2012; Zakeri, Esfahani, \& Razmjoee, 2013; Zeenath \& Orcullo, 2012). Various literature demonstrates that the academic procrastination's consequences affect failure in the learning process and educational achievement attainment (Asikhia, 2010; Esmaeili \& Monadi, 2016; Ojo, 2019). Additionally, academic behavior, such as learning attitude in school, motivation, and self-regulation (Karmen, Kinga, Edit, \& Susana, 2015), influence students' career, financial success, and potentially complicate the situation (Villanueva, 2011).

Based on the characteristics that provoke academic procrastination and identified issues, one of the fundamental causes of the soaring academic procrastination is self-regulated learning. This characteristic can negatively affect academic achievement. Pychyl \& Flett (2012) mention that procrastination is caused by the failure in self-regulation indicated by some problematic attitudes. Procrastinate behavior may corrupt the therapeutic process. Flett, Haghbin, \& Pychyl (2016) add that Rational Emotive Behavior Therapy (REBT) and Cognitive Behavioral Therapy (CBT) approach can effectively answer the complexity of procrastinator's self-regulation with inappropriate behavior. Therefore, this research aims to reduce academic procrastination through group counseling using self-instruction and timemanagement techniques. These two techniques are the modification of the cognitive-behavioral approach.

Self-instruction technique is perceived to be capable of improving academic procrastination since it enhances student's confidence and motivation in completing the tasks so that they possess better selfregulation skills. Additionally, the time management technique is also observed to be able to reduce academic procrastination because it enables students to monitor themselves in regulating their time to complete and submit the tasks in accordance with the deadline. In other words, these two techniques advance students' self-regulation so that they are expected to reduce academic procrastination in mathematic learning (Martin \& Pear, 2015).

Therefore, this study used a behavior modification technique based on the CBT approach in the form of group counseling to decrease academic procrastination. This research aims to: (1) test the group counseling's effectivity with self-instruction and time-management technique to lower academic procrastination in mathematic learning, and (2) test the effectivity differences between those two experiment group in decreasing academic procrastination in mathematic learning.

\section{METHOD}

This research was conducted in the 7th grade of State Junior High School 1 Wungu, Madiun District that has a significant level of academic procrastination (Asri et al., 2017). The research design used was randomized pre-test post-test comparison group design, with 208 students as the participant. By using a purposive random sampling technique, sixteen students were selected as a sample with a high academic procrastination level in mathematic learning. Later, the participants were divided into two groups, proportionally, using the random sampling technique. The member selection of those groups was carried out in accordance with Gladding (2012) so that the counseling process runs in a conducible manner. Group 1 received an intervention of the self-instruction technique, while Group 2 got an intervention of time management technique. The group dynamic during the counseling activity was heterogeneous due to the different causative factors and experiences from each student when they do academic procrastination in mathematic learning. 
The data collection process was conducted using an academic procrastination scale, adapted from The Procrastination Scale developed by Tuckman (1991). The scale was established based on three academic procrastination aspects, namely: (1) general self-image toward the tendency to delay working on a task (15 items), (2) tendency of avoiding tasks and boring stuff due to difficulties in finishing them (13 items), and (3) tendency to blame others for their situation ( 7 items).

The academic procrastination scale consists of 35 favorable and unfavorable items with five alternatives of always, frequently, occasionally, rarely, and never. According to the results of the validity test, four things were aborted so that the remaining 31 items were classified as valid with a correlation coefficient between $0.308-0.791$. At the same time, the results of the reliability test using Cronbach's Alpha showed a reliability coefficient of 0.897 .

The group counseling intervention for both groups was carried out by the school counselor. The study was started by the administration of inventory academic procrastination in mathematic learning pre-test for the research participant. Then, a treatment in the form of group counseling was provided for eight meetings, from February to March 2020. The duration of each session was 60 minutes to obtain indicators for each meeting objective. The counseling guidance consisted of the counseling plan for each student group. At the final meeting, a post-test was administered to each group to measure the results of group counseling in reducing academic procrastination.

The implementation of group counseling using the self-instruction technique was begun by the delivery of counseling's objectives, process, and benefits, according to the steps of group counseling by a counselor. In the next meeting, each member of the counseling group was asked to state their thought, feeling, behavior, and experience they have encountered, along with the causative factor of academic procrastination in academic learning. Further, each subject was provided by a self-instruction sheet. After the treatment was given, a group counseling reflection was conducted, along with the planning of students' new behavior with a positive thought. On the other side, students were provided with homework in the form of comparison material. The material for the task was adopted from the basic competencies taught by mathematic teachers in the school. The assignments were discussed in the next meeting, together with the mathematic teacher. On the final session, students were given a post-test sheet in the form of academic procrastination inventory in mathematic learning,

In addition, the time management group counseling consisted of two primary activities. The first activity was completed in the first meeting, where the counselor delivered the purpose, process, and benefits of group counseling using a time management technique. In the next meeting, each participant was asked to convey their thought, feeling, behavior, and the causative factors of academic procrastination in mathematic learning. After that, they were encouraged to establish self-awareness for their goals, find ways to manage their time to attain that goal, identify their routines and habits, as well as change their cognitive distortion. In the second activity, students were given a self-report sheet and asked to report their activities every day, create activity priority, find ways to obtain that priority, tell the feelings they encounter while working on the tasks, mention the time required to finish the assignments, do self-monitor in the time spent to complete the task, and implement them in a concrete step. The selfreport sheet contains concrete situations, such as, in an X situation, I will do Y to obtain Z. At the end of the effectivity, the participants were provided with mathematic tasks on comparison material with a deadline, to be discussed by the mathematic teacher later. In the next meeting, a reflection on the entire group counseling activities using time management was carried out, along with a post-test, in the form of academic procrastination inventory on mathematic learning.

The data analysis was carried out using the Wilcoxon Signed-Rank test to investigate group counseling with self-instruction and time management techniques. A strategy was used to eliminate confounding variables or unexpected variables, as well as the experimental situation factors, with no relation to the research objectives to overcome mistakes during the experiment. Mann-Whitney test was used to identify the different effectivity of two experimental groups. These two analysis techniques were chosen since the data was normally distributed. For both data analysis, SPSS 16.0 program for Windows was utilized. 


\section{RESULTS}

The descriptive analysis results of two experiment groups with group counseling using selfinstruction and time management techniques are presented in Table 1 and Table 2. Table 1 indicates that group counseling with self-instruction technique was attended by eight students, consisting of four male and four female students. The decrease of academic procrastination score on group counseling using self-instruction technique is $27 \%-30 \%$.

On the other hand, Table 2 presents that the participants attending group counseling using a time management technique were eight students, consisting of five female and three male students. After the students joined this counseling, their academic procrastination score in mathematic learning reduces by $14 \%-21 \%$.

The results of data analysis on the differences of group counseling using self-instruction and time management techniques to lessen academic procrastination is shown in Table 3, with $Z_{1}$ represents Wilcoxon Sign Rank test results, while $Z_{2}$ demonstrates the results of the Mann-Whitney test. According to Table 3, the results of the Wilcoxon Sign Rank reveal that counseling group with self-instruction and time management techniques are effective to lower the academic procrastination in mathematic learning $(Z=-2.524 ; p<0.05)$ and $(Z=-2.536 ; p<0.05)$, respectively.

Mann-Whitney test was used to test the different effectivity level of counseling group using selfinstruction and time management techniques in lowering academic procrastination in mathematic learning. The results show that the difference between these two techniques in reducing academic procrastination is $(\mathrm{Z}=-3.368 ; \mathrm{p}<0.05)$. The different effects of group counseling using self-instruction and time management techniques in reducing academic procrastination in mathematic learning is presented in Table 4.

Table 4 shows that group counseling using self-instruction technique in reducing academic procrastination in mathematic learning obtains pre-test and the post-test average score of 141.25 and 95.62 , respectively. This indicates a decrease in academic procrastination of 45.63 . Consequently, the

Table 1. Data of Pre-test and Post-test Academic Procrastination in Academic Learning from Group Counseling Using Self-Instruction Technique

\begin{tabular}{cccccc}
\hline Respondent & Gender & Pre-test & Post-test & Decrease & Percentage \\
\hline R-1 & Male & 141 & 97 & 44 & $27 \%$ \\
R-2 & Male & 140 & 96 & 44 & $27 \%$ \\
R-3 & Female & 139 & 90 & 49 & $30 \%$ \\
R-4 & Female & 141 & 96 & 45 & $27 \%$ \\
R-5 & Male & 147 & 99 & 48 & $29 \%$ \\
R-6 & Female & 137 & 98 & 39 & $24 \%$ \\
R-7 & Female & 141 & 95 & 46 & $28 \%$ \\
R-8 & Male & 144 & 94 & 50 & $30 \%$ \\
\hline
\end{tabular}

Table 2. Data of Pre-test and Post-test Academic Procrastination in Academic Learning from Group Counseling Using Time Management Technique

\begin{tabular}{cccccc}
\hline Respondent & Gender & Pre-test & Post-test & Decrease & Percentage \\
\hline R-1 & Female & 149 & 120 & 29 & $18 \%$ \\
R-2 & Male & 150 & 121 & 29 & $18 \%$ \\
R-3 & Female & 150 & 118 & 32 & $19 \%$ \\
R-4 & Female & 149 & 119 & 30 & $18 \%$ \\
R-5 & Male & 151 & 117 & 34 & $21 \%$ \\
R-6 & Female & 149 & 117 & 32 & $19 \%$ \\
R-7 & Female & 147 & 124 & 23 & $14 \%$ \\
R-8 & Male & 152 & 120 & 32 & $19 \%$ \\
\hline
\end{tabular}


Table 3. Results of Final Data Analysis

\begin{tabular}{lcccc}
\hline \multicolumn{1}{c}{ Intervention } & & Pre-test & Post-test & $\mathbf{Z}_{\mathbf{1}}$ \\
\hline Self Instruction & $\mathrm{M}$ & 141.25 & 95.62 & \\
& $\mathrm{SD}$ & 3.059 & 2.774 & -2.524 \\
Time Management & $\mathrm{M}$ & 149.62 & 119.50 & \\
& $\mathrm{SD}$ & 1.506 & 2.330 & -2.536 \\
$\mathrm{Z}_{2}$ & & -3.211 & -3.368 & \\
$\mathrm{p}$ & & 0.001 & 0.01 & \\
\hline
\end{tabular}

Table 4. Average Score of Pre-test and Post-test of Academic Procrastination from Both Experiment Groups

\begin{tabular}{lcccccc}
\hline \multicolumn{1}{c}{ J. } & N & Mean Pre-test & $\begin{array}{c}\text { SD } \\
\text { Pre-test }\end{array}$ & $\begin{array}{c}\text { Mean } \\
\text { Post-test }\end{array}$ & $\begin{array}{c}\text { SD } \\
\text { Post-test }\end{array}$ & Difference \\
\hline $\begin{array}{l}\text { Experiment Group 1 (self- } \\
\text { instruction) }\end{array}$ & 8 & 141.25 & 3.059 & 95.62 & 2.774 & 45.63 \\
$\begin{array}{l}\text { Experiment Group 2 (time } \\
\text { management) }\end{array}$ & 8 & 149.62 & 1.506 & 119.50 & 2.330 & 30.12 \\
\hline
\end{tabular}

academic procrastination decrease in mathematic learning after group counseling used the self-instruction technique is $32.30 \%$. Additionally, the time management group counseling attains pre-test and a posttest average score of 149.62 and 119, respectively, so that the decrease of academic procrastination is 30.12. This indicates a $20.13 \%$ decrease in academic procrastination after the participants attend group counseling using a time management technique.

After a pre-test was carried out in the form of academic procrastination inventory in mathematic learning, a post-test was administered to measure the academic procrastination decline after the implementation of group counseling using self-instruction and time management techniques. The posttest was given at the end of the experiment, in the eighth meeting. Each step completed in the group counseling process is based on the attainment indicator. Through analysis in pre-test and post-test average score differences, group counseling using self-instruction and time management are proven effective in reducing students' academic procrastination in mathematic learning. Further, the academic procrastination decrease is found higher in the counseling group with self-instruction (45.63) than in the counseling group using the time management technique (30.12). That happens since, with the selfinstruction technique, students were encouraged to improve their confidence using self-talk to control their thought, eliminate incorrect assumptions and beliefs, as well as bring self-motivation and selfregulation in learning and completing mathematic tasks.

The academic procrastination decrease in mathematic learning happens because of the participants enthusiastically attended the group counseling using self-instruction and time management technique. During the initial implementation of group counseling using the self-instruction technique, students encountered difficulties in the self-instruction process, yet the counselor encouraged them to reshape their cognitive pattern using self-talk so that students complete the task on time. Consequently, the subject started to show their confidence in transforming their irrational thoughts, so that new patterns appeared, along with rational assessment toward mathematic learning. Contrarily, in the initial implementation of group counseling using time management techniques, students seemed to enthusiastically tell their experiences in academic procrastination, primarily in mathematic learning. However, in the second activity, the students tended to exhibit indiscipline behavior in completing the self-report sheet, consisting of self-monitoring report in using the time to do the task and were incapable of managing the time. However, when the counselor tried to remind them, students demonstrated changes. On the other hand, students tended to see their friends' progress in completing the task on time as a trigger to do the same. 


\section{DISCUSSION}

Group counseling with the CBT approach using self-instruction and time management techniques is an effort to reduce academic procrastination. As explained by Erford (2016) that group counseling with the CBT approach aims to transform cognitive distortion and bring effective behavior. The decline in academic procrastination in mathematic learning obtained through group counseling using self-instruction is supported by various studies. Ozer, Demir, \& Ferrari (2013) conduct research in the form of groups using intervention to reduce academic procrastination. During the session, the participants' cognitive distortion that is associated with academic procrastination was identified. Other research also reveals that group counseling using self-instruction technique is sufficient to lower academic procrastination. It is supported by significant changes in five indicators of rational thinking patterns change toward academic tasks (Mardianingsih, Wibowo, \& Murtadlo, 2018). Besides, it is also supported by that aid students to boost their confidence through self-talk to control and motivate themselves to finish academic tasks (Fatimah \& Setiawati, 2013).

In addition, group counseling using time management techniques is also efficient in reducing academic procrastination in mathematic learning. During the counseling process, students were capable of completing the self-report consisting of self-monitoring reports in spending time to complete the task before the deadline. This result is in line with a study conducted by Yeganeh (2013) that explains time management focusses on-time control in finishing and submitting tasks, following the deadline. The participant better completes the assignments through time management by self-monitoring using a timer, taking note on the calendar or notebook, and working on the task, earlier. The findings of research conducted by Hussain \& Sultan (2010) also identify the factors of academic procrastination are lack of students' commitment, lack of self-encouragement, and lack of time management skills.

Another study on the implementation of time management to reduce academic procrastination is also carried out by Eerde (2003). The results of that research show that individual time management training aids the participant to face time pressure and accelerates their focus in controlling the time to complete more than one task at a time. Besides, a study conducted by Naturil-Alfonso et al. (2018) reveals that tasks with short or long deadlines result in students' academic procrastination that affects their academic achievement. Gafni \& Geri (2010) investigate the effects of time management techniques on academic procrastination. That research discovers that with the deadline, students tend to complete and submit the individual task on time, compared to the group task.

In addition, the results of the study also show different effectivity levels between group counseling using self-instruction and time management techniques in reducing academic procrastination in mathematic learning. Group counseling using self-instruction is detected to be more efficient in lowering academic procrastination than group counseling with time management technique. This is caused by the success of group counseling with self-instruction technique to improve students motivation to carry selfinstruction, change negative statement to positive statement, and repeat the self-instruction that enable them to do it, individually. The same results were encountered in the first activity of group counseling using time management that aim to transform the cognitive distortion. However, in the second activity, some students were found failed to submit their self-report about their time management in completing the mathematic tasks periodically. Consequently, the counselor tried to regularly encourage the participants to use time management in completing academic tasks to submit the assignments on time. The reflection results suggest that the participants felt burdened when they were asked to complete self-report since they were not habituated to manage their time during the counseling process. Besides, they wanted to avoid the responsibility to fill the self-report periodically. Therefore, the counselor tried to remind them to complete the self-report on time and honestly.

The application of these two CBT techniques was carried out in a group setting. The group dynamics are frequently used by the counselor to help students solve their problems. The school where this research was carried out also often uses a group setting. Even if the school's location is far from the city with less facility and infrastructure, and the students who mostly have low to middle socio-economy background, the group counseling with self-instruction and time management techniques have been successfully carried out. In this research, group dynamics clearly useful in reducing academic procrastination through the creation of a conducive counseling environment. Each participant is capable of delivering their 
ideas, feeling, and action completed while doing academic procrastination in mathematic learning. The ideas conveyed by each participant were carefully listened to by others. Besides, they also reply and give additional explanations whenever they find similar reasons for procrastinating.

The participants support each other efforts to reduce academic procrastination since they have recognized the effect of procrastination on their performance. Besides, the member in each group can motivate each other to transform their bad habit of postponing completing academic tasks. This result is in line with various previous research findings that show group setting can decline academic procrastination (Kadafi, Ramatus, \& Desy, 2018; Setiawan, 2015; Puswanti, 2014; Ramadhani \& Sari, 2018). Intrinsic motivation is required by students to lower academic procrastination. Thus, it involves students' cognitive and persistence when they encounter a difficult task so that they do not postpone working on the task (Asri et al., 2017).

In addition to those findings, this research still has a limitation in the sample selection process. It has not considered the demographic variable, such as different age and gender. Some studies discovered that gender differences affect the occurrence of academic procrastination (Balkis \& Erdinç, 2017; Khan, Arif, Noor, \& Muneer, 2014; Mandap, 2016). Additionally, this research implies that in mathematic learning, teacher's attitude during the teaching process significantly affects the academic procrastination. No matter how good a strategy is implemented in a class, but if the teacher does not implement discipline behavior and examine the submitted students' task or they fail to motivate students to do self-regulation in learning, then the academic procrastination will remain high.

\section{CONCLUSION}

After group counseling using self-instruction and time management techniques are carried out, the academic procrastination score of all participants in mathematic learning essentially decreases. Besides, the counseling group with the self-instruction technique is identified to be more effective in reducing academic procrastination than the counseling group using a time management technique. This information is essential for the school counselor before they implement group counseling to lower academic procrastination. Future research is expected to enforce these techniques to reduce academic procrastination in other courses or problems, enlarge the research sample, and use a demographic variable, such as gender difference.

\section{REFERENCES}

Afzal, S., \& Jami, H. (2018). Prevalence of academic procrastination and reasons for academic procrastination in university students. Journal of Behavioural Sciences, 28(1), 51-69.

Asikhia, O. A. (2010). Academic procrastination in mathematics: Causes, dangers and implications of counselling for effective learning. International Education Studies, 3(3), 205-210. https://doi.org//10.5539/ies.v3n3p205

Asri, D. N., Setyosari, P., \& Chusniyah, T. (2017). The academic procrastination in junior high school students mathematics learning: A qualitative study. International Education Studies, 10(9), 70-77. https://doi. org/10.5539/ies.v10n9p70

Azure, J. A. (2011). Correlates of course anxiety and academic procrastination in higher education. Global Journal of Educational Research, 10(1), 55-65

Balkis, M., \& Erdinç, D. (2017). Gender differences in the relationship between academic procrastination, satisfaction with academic life and academic procrastination. Electronic Journal of Research in Educational Psychology, 15(1), 105-125. https://doi.org/10.14204/ejrep.41.16042

Eerde, W. V. (2003). Procrastination at work and time management training. The Journal of Psychology: Interdisciplinary and Applied, 135(5), 421-434. https://doi.org.10.1080/00223980309600625

Erford, B. T. (2016). 40 techniques every counselor should know. Columbus, GA: Pearson Merrill/Prentice Hall.

Esmaeili, N., \& Monadi, M. (2016). Identifying the causes of academic procrastination from the perspective of male middle school male students. International Journal of Humanities and Cultural Studies, 2464-2487.

Fatimah, F. N., \& Setiawati, D. (2013). Penerapan teknik self-instruction untuk mengurangi perilaku off task siswa kelas X di SMK Negeri 12 Surabaya. Jurnal BK UNESA, 4(1), 259-265. 
Flett, A. L., Haghbin, M., \& Pychyl, T. A. (2016). Procrastination and depression from a cognitive perspective: An exploration of the associations among procrastinatory automatic thoughts, rumination, and mindfulness. Journal of Rational-Emotive and Cognitive-Behavioral Therapy, 34, 169-186.

Gafni, R., \& Geri, N. (2010). Time management: Procrastination tendency in individual and collaborative tasks. Interdisciplinary Journal of Information, and Management, 5(1), 115-125.

Gladding, T. S. (2012). Konseling: Profesi yang menyeluruh. Jakarta: Indeks.

Hadi, S., \& Novaliyosi. (2019). TIMSS Indonesia (trends in international mathematics and science study). Seminar Nasional \& Call For Papers Program Studi Magister Pendidikan Matematika, 562-569. Tasikmalaya: Universitas Siliwangi.

Haghbin, M., McCaffrey, A., \& Phychyl, T. A. (2012). The complexity of the relation between fear of failure and procrastination. Journal Rational-Emotive \& Cognitive-Behavior Therapy, 30(4), 249-263. https://doi. org/10.1007/s10942-012-0153-9

Hussain, I., \& Sultan, S. (2010). Analysis of procrastination among university students. Procedia Social and Behavioral Science, 1897-1904. https://doi.org/10.1016/j.sbspro.2010.07.385

Jiao, O. G., Daros-Voseles, D. A., Collins, K. M. T., \& Onwuegbuzie, A. J. (2011). Academic procrastination and the performance of graduate-level cooperative groups in research method courses. Journal of the Scholarship of Teaching and Learning, 11(1), 119-133.

Kadafi, A., Ramatus, M. R., \& Desy, R. N. K. (2018). Upaya menurunkan prokrastinasi akademik mahasiswa melalui bimbingan kelompok Islami. Jurnal EDUKASI (Media Kajian Bimbingan dan Konseling), 4(2), 181-193.

Karmen, D., Kinga, S., Edit, M., \& Susana, F. (2015). Associations between academic performance, academic attitudes, and procrastination in sample of undergraduate students attending different educational forms. Procedia-Social and Behavioral Sciences, 187(1), 45-49. https://doi.org/10.116/j.sbspro.2015.03.009

Khan, M. J., Arif, H., Noor, S. S., \& Muneer, S. (2014). Academic procrastination among male and female university and college students. FWU Journal of Social Sciences, 8(2), 65-70.

Mandap, C. M. (2016). Examining the differences in procrastination tendencies among university students. International Journal of Education and Research, 4(4), 431-436.

Mardianingsih, A. Y., Wibowo, M. E., \& Murtadlo, A. (2018). Self-instruction group counselling technique to reduce students academic. Jurnal Bimbingan Konseling, 7(1), 63-68.

Martin, G., \& Pear, J. (2015). Modifikasi perilaku. makna dan penerapannya (Y. Santoso, Trans.). Yogyakarta: Pustaka Pelajar.

Motie, H., Heidari, M., \& Sadhegi, M. A. (2012). Predicting academic procrastination during self-regulated learning in Iranian first grade high school students. Social and Behavioral Sciences, 69, 2299-2308. https:// doi.org/10.1016/j.sbspro.2013.02.023

Munawaroh, M. L., Alhadi, S., \& Saputra, W. N. E. (2017). Tingkat prokrastinasi akademik siswa Sekolah Menengah Pertama Muhammadiyah 9 Yogyakarta. Jurnal Kajian Bimbingan dan Konseling, 2(1), 26-31

Naturil-Alfonso, C., Peñaranda, D. S., Vicente, J. S., \& Marco-Jiménez, F. (2018). Procrastination: The poor time management among university students. In Fourth International Conference on Higher Education Advances.

Ojo, A. A. (2019). The impact of procrastination on students academic performance in secondary schools. International Journal of Sociology and Anthropology Research, 5(1), 17-22.

Ozer, U., \& Saricaoglu, H. (2013). An experimental study on academic procrastination: Effects of weekly homework. International Journal of Psycho-Educational Science Issue, 5(5), 1-7.

Park, S., \& Sperling, R. (2012). Academic procrastinators and their self-regulation. Scientific Research, 3(1), $12-23$.

Patrzek, J., Grunschel, C., \& Fries, S. (2012). Academic procrastination: The perspective of university counsellors. International Journal for the Advancement of Counselling, 34(3), 185-201. https://doi.org/10/1007/210447012-9150-z

Procee, R., Kamphorst, B., Meyer, J., \& Wissen, A. V. (2013). A formal model of procrastination. Journal RationalEmotive \& Cognitive-Behavior Therapy, 30(1), 1-15.

Puswanti. (2014). Upaya mereduksi prokrastinasi akademik melalui konseling kelompok dengan pendekatan behavioristik pada siswa SMK. PSIKOPEDAGOGIA, 3(1), 11-19.

Pychyl, T. A., \& Flett, G. L. (2012). Procrastination and self-regulatory failure: An introduction to the special issue. Journal of Rational-Emotive \& Cognitive-Behavior Therapy, 30, 203-2012. 
Ramadhani, E., \& Sari, K. (2018). Efektivitas layanan bimbingan kelompok menggunakan pendekatan discovery learning untuk mengurangi prokrastinasi akademik mahasiswa mengerjakan skripsi. Wahana Dikdaktika, 16(2), 193-206.

Saleem, M., \& Rafique, R. (2012). Procrastination and self-esteem among university students. Pakistan Journal of Social and Clinical Psychology, 9(3), 50-53.

Savira, F., \& Suharsono, Y. (2013). Self-regulated learning (SRL) dan prokrastinasi akademik pada siswa akselerasi. Jurnal Ilmiah Psikologi Terapan, 1(1), 61-74. https://doi.org/10.22219/jipt.v1i1.1358

Seperiah, F., \& Lotf, J. J. (2011). The effect of coping styles and gender on academic procrastination among university students. Journal of Basic and Applied Scientific Research, 1(12), 2987-2993.

Setiawan, M. A. (2015). Model konseling kelompok dengan teknik problem solving untuk meningkatkan selfefficasy akademik siswa. Jurnal Bimbingan Konseling, 4(1), 8-14. https://doi.org/10.15294/jubk.v4i1.6869

Talask, G., \& Carvalho, M. R. (2017). Cognitive behavioral based treatment for procrastination. Psychology and Behavioral Science International Journal, 8(1), 001-003.

Tuckman, B. W. (1991). The development and concurrent validity of the procrastination scale. Educational and Psychological Measurement, 5(1), 473-480. https://doi.org/ 10.1177/0013164491512022

Utaminingsih, S., \& Setyabudi, I. (2012). Tipe kepribadian dan prokrastinasi akademik pada siswa SMA "X" Tangerang. Jurnal Psikologi, 10(1), 48-57.

Ozer, B. U., Demir, A., \& Ferrari, J. R. (2013). Reducing academic procrastination through a group treatment program: A pilot study. Journal of Rational-Emotive \& Cognitive-Behavior Therapy, 31(3), 127-135.

Villanueva, M. T. (2011). Good things don't come to those who watchfully wait. Nature Reviews Clinical Oncology, 8(7), 386-386.

Widiseno, F. P., Purwanti, \& Wicaksono, L. (2018). Studi deskriptif perilaku prokrastinasi akademik pada peserta didik kelas VIII SMP Negeri 13 Pontianak. Jurnal Pendidikan dan Pembelajaran Khatulistiwa, 7(8), 1-9.

Wilson, B. A. (2012). Belonging to tomorrow: An overview of procrastination. International Journal of Psychological Studies, 4(1), 221-217.

Yeganeh, A. (2013). The effective strategies for preventing high school students' academic procrastination. European Online Journal of Natural and Social Sciences, 2(3), 666-671.

Zakeri, H., Esfahani, B. N., \& Razmjoee, M. (2013). Parenting styles and academic procrastination. Journal of Social and Behavioral Sciences, 84(1), 57-60. https://doi.org/https://doi.org/10.1016/j.sbspro.2013.06.509

Zeenath, S., \& Orcullo, D. J. C. (2012). Exploring academic procrastination among undergraduates. International Proceedings of Economics Development \& Research, 47(9), 42-46. 